
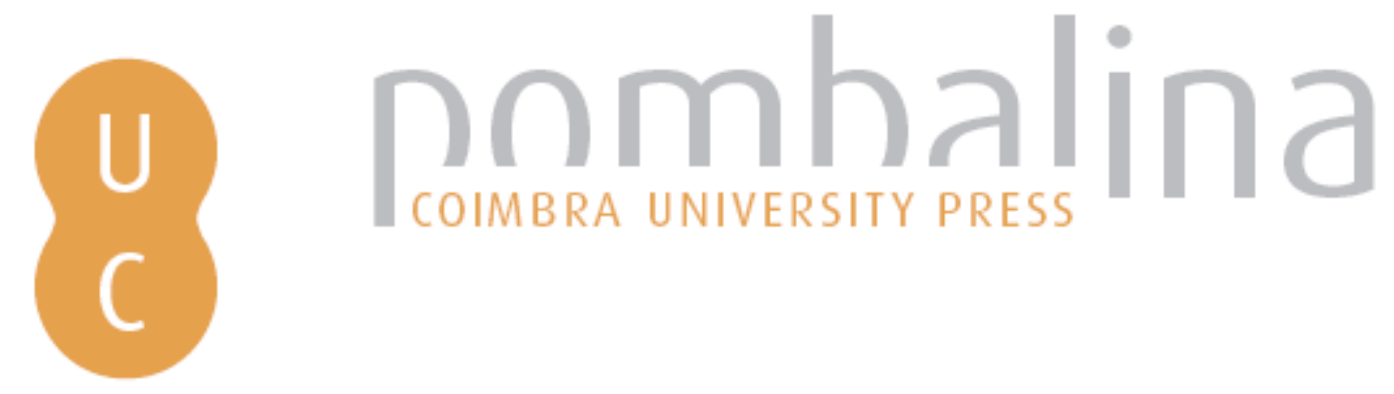

\title{
Um olhar a Oriente: imagens do mundo semítico na literatura grega, dos poemas homéricos e Xenofonte
}

\author{
Autor(es): $\quad$ Rodrigues, Nuno Simões
}

Publicado por: Imprensa da Universidade de Coimbra

URL

persistente: $\quad$ URI:http://hdl.handle.net/10316.2/32398

DOI: $\quad$ DOI:http://dx.doi.org/10.14195/978-989-26-0393-3_10

Accessed : $\quad$ 26-Apr-2023 16:33:00

A navegação consulta e descarregamento dos títulos inseridos nas Bibliotecas Digitais UC Digitalis, UC Pombalina e UC Impactum, pressupõem a aceitação plena e sem reservas dos Termos e Condições de Uso destas Bibliotecas Digitais, disponíveis em https://digitalis.uc.pt/pt-pt/termos.

Conforme exposto nos referidos Termos e Condições de Uso, o descarregamento de títulos de acesso restrito requer uma licença válida de autorização devendo o utilizador aceder ao(s) documento(s) a partir de um endereço de IP da instituição detentora da supramencionada licença.

Ao utilizador é apenas permitido o descarregamento para uso pessoal, pelo que o emprego do(s) título(s) descarregado(s) para outro fim, designadamente comercial, carece de autorização do respetivo autor ou editor da obra.

Na medida em que todas as obras da UC Digitalis se encontram protegidas pelo Código do Direito de Autor e Direitos Conexos e demais legislação aplicável, toda a cópia, parcial ou total, deste documento, nos casos em que é legalmente admitida, deverá conter ou fazer-se acompanhar por este aviso.

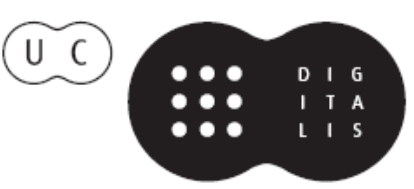




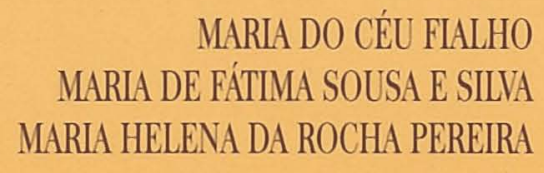

Coordenação

\section{Génese e consolidaç̃ão da ideia de Europa} Vol. I: de Homero ao fim da época clássica 
MARIA DO CÉU FIALHO

MARIA DE FÁTIMA SOUSA E SILVA

MARIA HELENA DA ROCHA PEREIRA

Coordenação

\section{Génese e consolidação da ideia de Europa}

Vol. I: de Homero an fim da época clíssica 


\title{
Coordenação editorial
}

Imprensa da Universidade de Coimbra

\section{Concepção gráfica}

António Barros

\section{Paginação}

Victor Hugo Fernandes

\section{Execução gráfica}

SerSilito - Maia

\section{ISBN}

972-8704-57-7

\section{Depósito Legal}

234088/05

(C) Outubro 2005, Imprensa da Universidade de Coimbra

\author{
Obra PUblicada COM O FINANCIAMENTO DE:
}

Centro de Estudos Clássicos e Humanísticos

$$
\text { FCT Fundaçāo para a Ciência e a Tecnologia }
$$

OBRA PUBLICADA COM O APOIO DE:

FCT: Fundação para a Ciência e Tecnologia - Ministério da Ciência e do Ensino Superior Apoio do Programa Operacional para a Ciência, Tecnologia, Inovação do III Quadro Comunitário de Apoio 



\section{UM OLHAR A ORIEnTE: \\ ImAGENS DO MUNDO SEmítico NA Literatura Grega, dos \\ POEMAS HOMÉRICOS A XENOFONTE}

Nuno Simões Rodrigues

(Universidade de Lisboa)

As culturas do ramo linguístico semítico tiveram o seu apogeu civilizacional entre o II. ${ }^{\circ}$ milénio e o século VI a.C. Durante esse período, Babilónios, Assírios, Hebreus, Cananeus e Fenícios instalaram-se, criaram e desenvolveram formas estatais e administrativas num território que, grosso modo, se estendia da Mesopotâmia ao litoral siro-palestinense, também conhecido como Canaã. Os Gregos foram, entre os povos europeus, aqueles que mais próximos estiveram dessas culturas, pelo que não é de estranhar que se encontrem imagens, vestígios ou até mesmo influências do mundo semítico na cultura grega ${ }^{(1)}$. Esse intercâmbio ocorreu essencialmente em dois períodos da História helénica, o micénico e o século VIII a.C., quando os contactos entre Ocidente e Oriente, derivados das expedições comerciais, primeiro, e do processo de colonização, depois, foram particularmente acentuados $^{(2)}$. São vários os elementos que hoje nos permitem atestar essas relações. Deste segundo período conhecemos inclusive casos pontuais

(1) Cypr. frg. 1 Davies sugere o cruzamento de povos. Sobre a História comum de Gregos e orientais, ver C. Baurain, Les Grecs et la Méditerranée orientale. Des siècles obscurs à la fin de l'époque archaïque (Paris, 1997).

${ }^{(2)}$ M.L. West, The East Face of Helicon. West Asiatic Elements in Greek Poetry and Myth (Oxford, 1997), e idem, «The Rise of the Greek Epic», Journal of Hellenic Studies 108 (1988), 169. 
que testemunham o contacto intercultural. Antiménides, irmão do poeta Alceu, foi provavelmente mercenário na Babilónia de Nabucodonosor, por exemplo ${ }^{(3)}$. Assírios e Gregos estiveram em contacto directo a partir de aproximadamente 800 a.C. e sabemos de uma batalha entre estes dois povos, ocorrida depois de 700 a.C.(4) Pinturas em vasos dessa data representam motivos orientalizantes; Hesíodo menciona o vinho de Biblos e Burkert chama a atenção para a coincidência entre a época da primeira transcrição da Ilíada e a criação da biblioteca de Assurbanípal ${ }^{(5)}$. Os Gregos de Eubeia estabeleceram, inclusive, entrepostos comerciais na Síria setentrional, perto do Orontes, em finais do século $\mathrm{IX}^{(6)}$. Em contrapartida, detectam-se artesãos fenícios instalados nessa ilha ${ }^{(7)}$. Um documento acádico, datado de c. 738 a.C., procedente da Síria, menciona o povo que vem da «terra Iaunaia», muito possivelmente a Jónia ${ }^{(8)}$. Por certo, houve mais contactos com outros povos orientais, nomeadamente os Hititas, Egípcios, Arameus e Cananeus. Outro dado importante é a chegada do alfabeto à Grécia. A escrita grega, juntamente com o rolo e a tabuinha de escrever, chegou à Hélade a partir da Síria, no século VIII ${ }^{(9)}$. É também aceite que o carro de guerra, invenção oriental do II. milénio a.C., ficou a ser conhecido pelo mundo grego via Síria ${ }^{(10)}$. Em síntese, podemos mesmo afirmar que foram vários os canais da transmissão: o político-social, o iconográfico, o literário, o tecnológico e, como veremos, também o ritual.

(3) Alc. frg. 350 Lobel-Page. O frg. 48 refere-se igualmente a Babilónia e à destruição de Ascalão em 604 a.C.

(4) A. Momigliano, «Su una battaglia tra Assiri e Greci», Athenaeum 12 (1934), 4.12-4.16.

(5) Hes., Op. 582; W. Burkert, "Rasgos orientalizantes en Homero» in De Homero a los Magos. La tradición oriental en la cultura griega (Barcelona, 2002), p. 51.

(6) M.L. West, «The Rise of the Greek Epic», 170, traça aquele que pensa ser o mapa da difusão cultural nesse período: Síria, Chipre, Rodes, Creta, Ática e Eubeia foi o itinerário provável da aculturação, considerando-se a Eubeia, um local de colonização fenícia, com apetência para esses contactos; até mais que a Ásia Menor.

(7) B. Powell, "Homer and Writing» in A New Companion to Homer, ed. I. Morris and B. Powell (Leiden, 1977), pp. 3-32, escreve inclusive que terá sido nessa ilha que o alfabeto foi inventado.

(8) Citado por W. Burkert, «Rasgos orientalizantes en Homero», 14-15.

(9) M.H. Rocha Pereira, Estudos de História da Cultura Clássica, vol. I - Cultura Grega (Lisboa, 1997), p. 18; W. Burkert, The Orientalizing Revolution. Near Eastern Influence on Greek Culture in the Early Archaic Age (London, 1995), pp. 25-33; idem, "Rasgos orientalizantes en Homero", 59; R. Woodward, Greek Writing from Knossos to Homer (Oxford, 1997).

${ }^{(10)}$ J.H. Crouwel, Chariots and other means of land transport in Bronze Age Greece (Amsterdam, 1981). 


\section{As IMAGENS INCONSCIENTES}

Desde os seus primórdios que a literatura grega contém imagens de ambiente semítico. Estas começam por ser breves flashes que coexistem com referências concretas, assumidas como orientais, que hoje classificamos como semíticas, e assim identificadas pelos próprios agentes literários. Mas nestes suspeitamos igualmente de uma influência, tácita, de tal ambiente, através de paralelismos entre formas e conteúdos literários que permitem equacionar esta problemática ao nível da derivação ou até mesmo da origem cultural comum ${ }^{(1)}$. Cabem nesta categoria exemplos das afinidades linguístico-vocabulares. Elas estão presentes ao nível da onomástica, como demonstram os casos de "Cíniras" e "Cadmo". Mas há outros. Tisbe $(\Theta i ́ \sigma \beta \eta)$, por exemplo, a heroína babilónica, possui um nome que se assemelha foneticamente ao da origem do profeta Elias, o tisbita (תשבי, $t s h b h)^{(12)}$. O nome da heroína surge apenas em poetas tardios e Ovídio assume a sua origem semítica; porém, a Ilíada menciona uma cidade com o mesmo nome ${ }^{(13)}$. Existe um paralelismo fonético entre o «Jordão»

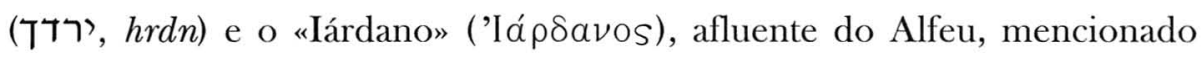
na Ilíad $a^{(14)}$. Há também o vocabulário aparentemente comum a Gregos, Hebreus e por vezes a Acádios. J.P. Brown estudou em particular os nomes de algumas especiarias e perfumes. São exemplos a cássia (קציעה, qtsh hh, em

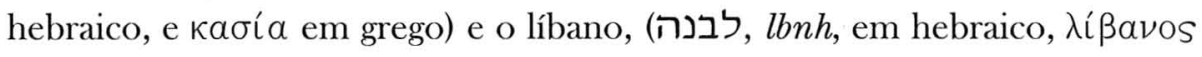
em grego, e labnanu em acádico). Em Safo, no epitalâmio para Heitor e Andrómaca, aparecem os dois perfumes. Esse é um verso semelhante a um outro que encontramos nos Salmos:

(11) Ao nível dos conteúdos temáticos, M.L. West, "The Rise of the Greek Epic», 170, sintetizou as afinidades entre a epopeia grega e as orientais: o tema da destruição da humanidade por excesso de população; o herói irado que é controlado por duas deusas; o herói que pede à sua mãe divina que interceda por si junto de um deus superior; a deusa do amor que se queixa aos pais de agressão humana; a deusa que se veste com os trajes feitos pelo ferreiro dos deuses para um encontro amoroso; o ferreiro dos deuses que faz armas especiais para o herói; o herói que chora a morte do seu companheiro como um «leão»; e o espírito do companheiro morto que o visita, vindo do mundo inferior; ao nível da forma, destaca-se essencialmente a utilização de símiles, de epítetos formulares, do discurso directo, da repetição de cenas-tipos e da poesia de catálogo.

${ }^{(12)}$ Cf. Ov., Met. IV, 55-168 e 1Rs 17,1.

(13) Il. II, 502.

(14) Il. VII, 135. 


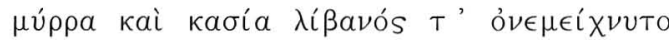

«misturaram-se a mirra e a cássia e o líbano» ${ }^{(15)}$

מר-ואהלות קציעות כל-בגדתיך

«As tuas vestes exalam mirra, aloés e cássia» ${ }^{(16)}$,

sendo a frase bíblica igualmente entendida como parte de um epitalâmio para uma princesa de Tiro. Brown considera que os nomes das especiarias e perfumes orientais chegaram à Grécia importados do mundo semítico, sendo por isso significativo que a cássia, o líbano ou o nardo sejam também mencionados por Alceu, Heródoto, Eurípides, Hipócrates, Píndaro, Platão e Empédocles ${ }^{(17)}$.

Mas não são exclusivamente os nomes das especiarias ou perfumes que encontram paralelos entre as línguas grega e semíticas. São muitos outros os casos em que isso acontece, destacando-se como exemplos o vocábulo $\lambda i ́ s$, «leão» em Homero, (Pseudo-)Hesíodo, Hipónax e Eurípides ${ }^{(18)}$, que

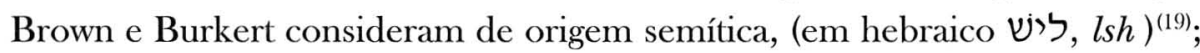
o nome do altar para o sacrifício, $\beta \omega \mu$ ós em grego, tal como aparece na

${ }^{(15)}$ Sapph., frg. 44 Lobel-Page.

(16) Sl. 45,9. Note-se que «Cássia» é também o nome de uma das filhas de Job. Cf. $J b 42$, 14.

(17) Alc., frg. 50 Lobel-Page; Sapph., frg. 2 Lobel-Page; Hdt. II, 86; E., Ba. 144. (tendo como contexto o ciclo de Cadmo); Pi., frgs. 107, 114 Bowra; Pl., Lg. VIII, 847B; Emp. VI, 2. Cf. J.P. Brown, Israel and Hellas (Berlin/New York, 1995), pp. 70-72; neste autor pode encontrar-se o estudo de diversas analogias temático-vocabulares, como as relacionadas com o nardo ou o vinho, por exemplo. Sobre a questão dos perfumes e das especiarias no mundo grego ver ainda M. Detienne, Les jardins d'Adonis (Paris, 1982). Outro nome que surge na cultura grega com possível afinidade com as culturas semíticas é o célebre néctar homérico. Efectivamente, véктap aproxima-se do niph'l hebraico נקטר, nqtr, derivado de קטר, «a fumaça do sacrfício ou incenso». Mas não existe uma correspondência directa entre o que significava o néctar para os Gregos e o incenso para os Hebreus. Além disso, este niph'l é atestado apenas tardiamente no hebraico, enquanto o néctar aparece muito cedo na literatura grega. Cf., e.g. Sapph., frg. 2 Lobel-Page e

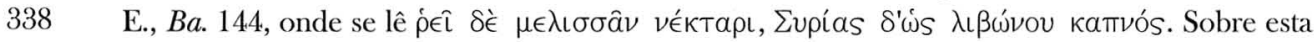
questão, ver S. Levin, «The Etymology of vékтap: Exotic Scents in Early Greece», Studi Miceni ed Egeo-Anatolici 13 (1971), 31-50.

(18) Aparece, por exemplo, em Il. XI, 480; XV, 275; Hes., Sc. 172; Hippon. frg. 124 Bergk.

${ }^{(19)}$ W. Burkert, The Orientalizing Revolution, 39, n. 30 e J.P. Brown, «Literary Contexts of the Common Hebrew-Greek Vocabulary», Journal of Semitic Studies 13 (1968), 163-191. Outros

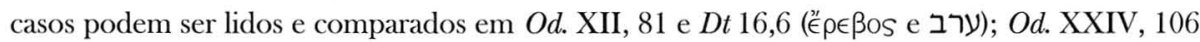

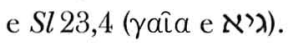


Odisseia, em Ésquilo, em Baquílides, em Safo ou em Píndaro ${ }^{(20)}$, lembra a (bamah) hebraica ${ }^{(21)}$. Ainda em relação ao altar, é possível encontrar uma frase em Baquílides que lembra uma recomendação do Deuteronómio ${ }^{(22)}$. É verdade que, em rigor, estas comparações pouco ou nada provam, dado que a antiguidade do termo original não é evidente ${ }^{(23)}$. Tratar-se-á efectivamente de importação directa e difusão ocidental via Oriente semítico ou de coincidências? Mas, de qualquer modo, a sua existência é, por si só, pertinente.

A inconsciência das imagens semíticas parece estar igualmente presente nas afinidades mitológicas que parecem ser produto de um decalque ou transferência directa. O tema da tábua das nações, dos descendentes de Deucalião, sobrevivente do dilúvio grego, por exemplo, aparece nas culturas grega e hebraica: Hélen (Helenos), Doro (Dórios), Aqueu (Aqueus), Éolo (Eólios) e Íon (Jónios) surgem como heróis epónimos, a partir dos quais se formou a Grécia. Essa é uma noção presente já em Heródoto ${ }^{(24)}$. O tema tem uma variante ligada ao ciclo tebano e, tal como a anterior, a árvore de Cadmo em Apolodoro pode também comparar-se à do Génesis, onde os epónimos são Sem (Semitas), Cam (Camitas) e Jafet (Jafetitas, entendidos como os Indo-Europeus), funcionando este como epónimo dos Jónios ${ }^{(25)}$. Igual ressonância tem o mito dos Alóadas, contado na Odisseia. Filhos de Posídon, Oto e Efialtes eram gigantes que decidiram defrontar os deuses. Para isso, empilharam três montanhas, ameaçando chegar ao céu. Acabaram

(20) Od. XIII, 187; A., A. 383; B. XI, 110-111; Sapph., frg. 2 Lobel-Page; Pi., frg. 114 Bowra.

(21) $1 R s$ 3,4; Js 22,10; Dt 12,27. Este caso em particular pode ser estudado em F. Aspesi, «Semitico bm.t e gr. $\beta \omega \mu$ ós» in Linguistica e Filologia, ed. G. Bolognesi et al. (Milano, 1984), pp. 179-186. Sobre o tema em geral pode ainda ver-se E. Masson, Recherches sur les plus anciens emprunts sémitiques en grec (Paris, 1967).

${ }^{(22)}$ Dt 12,27 e B. XI, 110-111.

${ }^{(23)}$ Assim como nada provam as reflexões feitas por Brown em relação ao uso do tamborete em Israel (ת) e na Grécia (Tú desse instrumento em E., Ba., passim, e Cyc. 63-67 e Ar., Lys. 387-389 com Is 24,7-9; Ex 15,20 e $J d t$ 16,20, onde Miriam e Judite dançam ao mesmo tempo que tocam o instrumento. Pensamos, porém, que isso não confirma a origem semítica do tamborete, podendo tratar-se apenas de um comportamento comum às sociedades antigas.

${ }^{(24)}$ Hdt. I, 56; VII, 94; cf. Apollod., Bibliotheca I, vii, 2-3; Ov., Met. I, 125-415. Em E., Ion, passim, Íon não é filho de Xuto e neto de Hélen, mas sim de Apolo.

(25) Apollod., Bibliotheca II, i, 3-4 e Gn 10. Jafet tem sido relacionado e identificado com Jápeto, cf. Hes., Th. 507-510. 
por ser derrotados por Apolo ${ }^{(26)}$. A história dos Alóadas encontra eco nas figuras dos filhos dos anjos bíblicos e na torre de $\mathrm{Babel}^{(27)}$. Outros paralelos podem ser verificados nas histórias de Nestor e David, ambos carrascos de um gigante durante a juventude ${ }^{(28)}$. A descrição de Golias sugere mesmo a imagem de um soldado grego ${ }^{(29)}$. Héracles e Sansão são duas das personagens com mais afinidades temáticas na estrutura das lendas que lhes eram atribuídas. Ambos homens de força desmesurada, ambos com uma forte

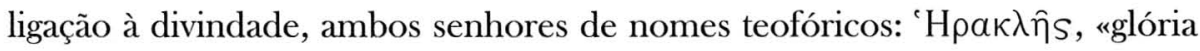
de Hera", e Shamash, o deus acádico do sol. Juntem-se os combates com o leão, a ira contra as primeiras esposas de ambos e a traição feminina de Dejanira e Dalila, que leva os heróis à morte, e torna-se difícil não estabelecermos uma relação temática entre as duas figuras ${ }^{(30)}$. Acresce ainda a origem danaíta de Sansão, o que nos faz pensar nos Dánaos ${ }^{(31)}$. Podemos também destacar a história de José na Bíblia, próxima do episódio de Belerofonte na Ilíada e da lenda de Hipólito. O tema do jovem atraente por quem a mulher do seu benfeitor ou protector se apaixona e que, sendo repudiada, o acusa falsamente de sedução é o denominador comum a estes três heróis ${ }^{(32)}$. De igual modo, a carta que Belerofonte transporta para a Ióbates com a sua sentença de morte recorda a que Urias leva a Joab, no

(26) Od. XI, 305-320; são também mencionados na Il. V, 389-390; cf. Apollod., Bibliotheca I, vii, 4 .

(27) Gn 6,1-8; 11,1-9.

(28) $\mathrm{Il}$. VII, 124-160 e $1 \mathrm{Sm}$ 17,12-51. Nestor confessa tê-lo feito junto às margens doJárdano. O tema aparece igualmente no contexto egípcio do combate contra o herói de Retenu, na Narrativa de Sinhué e no de Ulisses e o Ciclope, na Od. IX, 187-435.

${ }^{(29)}$ J.P. Brown, Israel and Hellas, 164, destaca os paralelos vocabulares que compõem a armadura do gigante com nomes gregos e considera a descrição de Golias no primeiro livro de Samuel coeva da Ilíada.

(30) A história de Sansão vem relatada em $J z$ 13,1-16 e a de Héracles em várias fontes, de que destacamos os textos mais antigos: $\mathrm{Il}$. V, 392-394, 638-650; VIII, 366-370; XI, 690-691; XIV, 250-253; XV, 25-26; Od. XI, 623; Hes., Th. 287-293, 313-315, 326-331, 979-983; Hes., Sc. 359ss.; B. V, 56ss.; VIII, 6ss.; Pi., O. III, 29ss.; X, 26ss.; I. VI, 38ss.; X, 26ss.; P. I, 63ss.; V, 69ss.; X, 2; A., Pr.; S., Tr.; Aj. 1299ss.; Hdt. IV, 8; VIII, 3; E., HF; Ion 194; Heracl. 740ss.; Pl., Grg. 484b. Uma análise do ciclo de Sansão pode ser lida em J. Kim, The Structure of the Samson Cycle (Kampen, 1993).

${ }^{(31)}$ Este é um problema complexo com imensa bibliografia, de que destacamos G. Coelho Dias, Hebreus e Filisteus na terra de Canaã. Nos pródromos da questão palestiniana (Porto, 1994).

(32) Cf. Gn. 39,1-23; Il. VI, 155-226; E., Hipp.. O tema está também presente num texto egípcio, $O$ conto dos dois irmãos. 
momento em que David planeia a morte do hitita ${ }^{(33)}$. O confronto entre Héracles e Euristeu assemelha-se ao de Jacob e Esaú(34). O encontro de Ulisses e Nausícaa na Odisseia tem muitas afinidades com os de Isaac e Rebeca e Jacob e Raquel, no Génesis, e o de Moisés e Séfora no livro do $\hat{E} x o d o^{(35)}$. E até a história de Dina e os Siquemitas poderia ser relacionada com a de Helena e os Troianos ${ }^{(36)}$. O mito das divindades caídas surge nas figuras dos Titãs, como nos $n^{e}$ philim do Génesis, como também no Enuma Elish ${ }^{(37)}$. Outro tema comum é o da assembleia dos deuses, que aparece, por exemplo, na Odisseia, no livro de Job e no Gilgamesh, onde se decide a morte de Enkidu ${ }^{(38)}$. Muitos paralelos de lendas gregas com as culturas semíticas foram estudadas por M.C. Astour, que acredita que os temas, mais importantes que algum tipo de racionalização mitológica, são o cerne dos mitos. Astour conclui mesmo que deve ter existido uma colónia de origem semítica na Argólida e na Beócia, centros em torno dos quais se desenvolveram ciclos mitológicos em que o autor identifica raízes semíticas. Aquelas teriam acabado por ser helenizadas, mas os vestígios ter-se-iam mantido na toponímia e na mitonímia ${ }^{(39)}$.

Outro aspecto da comunidade e da possível transmissão de uma imagem do Oriente semítico através da Grécia assenta na religiosidade, no culto e

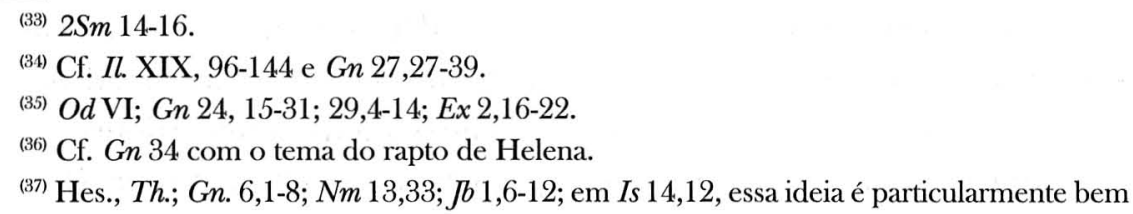

${ }^{(37)}$ Hes., Th.; Gn. 6,1-8; $N m$ 13,33; Jb 1,6-12; em Is 14,12, essa ideia é particularmente bem expressa; Enuma Eliesh.

(38) Od. I, 11-95; Jb. 1,6; Sl. 82,1; 89,8; Gilgamesh VII, 1; VIII, 1-92. Cf. C.H. Gordon, "Homer and Bible. The Origin and Character of East Mediterranean Literature», Hebrew Union College Annual 26 (1955), 43-108 (por vezes demasiado forçado); A.F. Campbell, «Homer and Ugaritic Literature», Abr-Nahrain 5 (1964-1965, 1966), 29-56 e S. Morris, «Homer and the Near East» in A New Companion to Homer, eds. I. Morris, B. Powell, eds. (Leiden/New York/Köln, 1997), pp. 599-623.

(39) M.C. Astour, Hellenosemitica: An Ethnic and Cultural Study in West Semitic Impact on Mycenaean Greece (Leiden, 1965), pp. 14.0, 113-224. Astour acredita que os mitos terão sido transferidos do Oriente para a Grécia algures durante o período micénico e relaciona todo o ciclo de Cadmo com a mitologia ugarítica; críticas a esta comparação podem ser lidas em R.B. Edwards, Kadmos the Phoenician. A Study in Greek Legends and the Mycenaean Age (Amsterdam, 1979), pp. 142-161. Ver ainda M.C. Astour, "Greek Names in the Semitic world and Semitic names in the Greek world», Journal of Near Eastern Studies 23 (1964), 193-201. Sobre as conexões semíticas da Beócia, E. Porada, «The Cylinder Seals Found at Thebes in Beotia», Archiv für Orientsforschung 28 (1981), 1-78. 
no rito. Afrodite é a deusa com mais conexões semitizantes. Vários aspectos do seu mito identificam-se com lendas de Ishtar, não apenas ao nível das características que a definem como divindade, como inclusivamente ao nível da intervenção mitológica. O passo da Ilíada em que Afrodite é ferida por Diomedes é o que tem suscitado mais estudos. Ao ver o ỉ ẃp que corre do ferimento, a deusa corre para o Olimpo, procurando consolo no colo de sua mãe, Dione ${ }^{(40)}$. Trata-se de uma cena semelhante à da Epopeia de Gilgamesh, quando Ishtar é rejeitada pelo herói e procura apoio nos altos céus, junto do seu pai Anu e da sua mãe $A n t u^{(41)}$. Quer Afrodite quer Ishtar acabam por ser repreendidas pelos respectivos pais. Burkert chamou já a atenção para o facto de as duas cenas serem paralelas em estrutura, forma narrativa e ethos $^{(42)}$. As personagens são as mesmas: o deus do céu, a sua esposa e a sua filha, a deusa do amor. Na verdade, Dione parece ter aqui substituído Hera, que é uma deusa fundamental para a economia do poema. Aliás, este é o único passo da Ilíada em que Dione aparece, o que sugere a importação de toda uma cena para a epopeia. Mais, o nome da mãe de Afrodite é aqui resultado da forma feminina

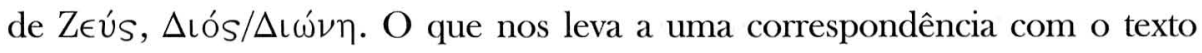
acádico, onde o nome da mãe de Ishtar, Antu, corresponde à forma feminina do nome do pai, $A n u$ («Céu»), o que levou à hipótese de se estar perante uma dependência homérica da Epopeia de Gilgamesh ${ }^{(43)}$. Nesta linha de pensamento, as hipóteses acerca da origem semítica de Afrodite também não faltam, baseadas nos atributos da deusa, nas particularidades do seu culto, nas afinidades com Ishtar e Astarte, no envolvimento com personagens como Adónis e até na proximidade linguística do seu nome grego com o semítico Ashtorith ${ }^{(44)}$.

(40) Il. V, 330-431.

(41) Gilgamesh VI, 1-91.

(42) A mesma cena acontece ainda na Il. XXI, 505-513, com Ártemis. De igual modo, o tema do dolo de Zeus parece ter um passado orientalizante, como o catálogo das mulheres amadas por Zeus parece ser um contraponto dos amantes de Ishtar, Gilgamesh VI, 53-57 e Il. XIV, 315-328; W. Burkert, «Rasgos orientalizantes en Homero», 27-29, 43.

${ }^{(43)}$ W. Burkert, «Rasgos orientalizantes en Homero», 45, e J.P. Brown, Israel and Hellas, 328, onde o autor trata as divindades como Sky and Mrs. Sky. Nesta linha de raciocínio, M.L. West, «The Rise of the Greek Epic», 169-170, afirma que «It is hardly going too far to say that the whole picture of the gods in the Iliad is oriental.»

(44) W. Burkert, «Rasgos orientalizantes en Homero», 44; V. Pirenne-Delforge, L'Aphrodite grecque (Liège, 1994) e W. Burkert, The Orientalizing Revolution, 202, n. 18, e C. Bonnet et V. Pirenne-Delforge, «Deux déesses en interaction: Astarté et Aphrodite dans le monde égéen» in Les syncrétismes religieux dans le monde Méditerranéen Antique, ed. C. Bonnet, A. Motte (Bruxelles/Roma, 1999), 249-273. 


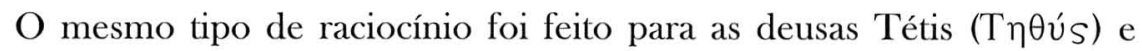
Tiamat ou Tawtu, personagens da Ilíada e do poema babilónico Enuma Elish. Em acádico, tiamtu, de onde deriva o nome da deusa no poema, significa «mar» e, na cultura grega, Tétis é uma divindade marinha. Mais, a forma grega em causa corresponde à trancrição exacta da forma acádica, como provam as referências do pintor Sófilo e de Eudemo, discípulo de Aristóteles, que teria conhecido o poema em tradução. Considerações que levaram à hipótese de, no coração da Ilíada, poderem encontrar-se influências de textos acádicos ${ }^{(4.5)}$. Os exemplos poderiam multiplicar-se, se analisássemos em pormenor as cosmogonias e teogonias das culturas em causa ${ }^{(46)}$.

${ }^{(45)}$ Eudem., frg. 150 Wehrli. Formulação de W. Burkert, «Rasgos orientalizantes en Homero", 23, 28, e The Orientalizing Revolution, 93, 202 e J. Duchemin, Mythes Grecs et Sources Orientales (Paris, 1995). Outros exemplos: comparação do comportamento de Penélope em Od. IV, 759-767 e de Ninsun em Gilgamesh III, 2; e de Il.I, 396-406 com o Atrahasis I, 27-102. O mesmo tipo de estudo foi feito por J.P. Brown, Israel and Hellas, 181-182, para o Fineu grego e o Fineias bíblico. O estudo comparativo das fontes e das raízes dos seus nomes leva à conclusão da grande afinidade das suas personagens; cf. $1 S m$ 3,2; 4,17 e Hes. frg. 157 Merkelbach-West (tema do vidente cego); $1 S m$ 2,13 e A.R. II, 188 (tema do banquete roubado); $1 S m$ 2,23; 4,11 e S., Ant. 966-976 e Apollod., Bibliotheca III, xv, 3 (tema dos filhos desrespeitadores); e a etimologia do nome: em hebraico, $p n \hat{E} s$ significa «o negro» e Fineu era irmão do rei da Etiópia, Apollod., Bibliotheca II, iv, 3. Outro exemplo pertinente é o das histórias de Andrómeda e Jonas, tendo em comum o cenário fenício de Jopa e o monstro marinho. Cf. Jn 1-2 e T.B.L. Webster, The Tragedies of Euripides (London, 1967), p. 193, onde se cita a representação de Andrómeda em trajes orientais em vasos do século $\mathrm{V}$ a.C., muito provavelmente relacionada com as tragédias homónimas de Sófocles e Eurípides, hoje perdidas. Mas as trocas podem ter sido bilaterais. Perante as semelhanças entre um passo da Ilíada e os Anais de Senaqueribe, referentes à batalha de Halule (691 a.C.), Burkert coloca a hipótese de um cantor grego ter chegado à Síria junto com mercenários gregos e ter composto o passo dos Anais, inspirando-se na figura de Aquiles para construir a de Senaqueribe. Este rei é mencionado em Hdt. II, 141, no contexto da peste causada pela praga de ratos.

(46) Recordamos que Hesíodo parece ter sido contemporâneo da composição do Génesis. Sobre essa questão ver G.S. Kirk, "The Structure and Aim of the Theogony» in AA.VV., Hésiode et son influence (Genève, 1960), pp. 61-107; P. Walcot, "Hesiod and the Didactic Literature of the Near East", Revue des Études Grecques 358 (1962), 13-16; H. Erbse, «Orientalisches und Griechisches in Hesiods Theogonie", Philologus 108 (1964), 2-28; P. Walcot, Hesiod and the Near East (Cardiff, 1966); F. Solmsen, «The two Near Eastern Sources of Hesiod», Hermes 117 (1989), 413-422; MJ. Luzzato, «Grecia e Vicino Oriente: tracce della Storia di Ahiqar», Quaderni di Storia 18 (1992), 5-84; M.L. West, «The Rise of the Greek Epic», 171 (onde se afirma que a «Theogony is built on the framework of an oriental history of the gods» e que «Works and Days on the pattern of an oriental wisdom poem, his myth of Ages as oriental»); idem, The East Face of Helicon, passim e C. Penglase, Greek Myths and Mesopotamia. Parallels and Influence in the Homeric Hymns and Hesiod (London/New York, 1994). Hesíodo tem sido porém, mais relacionado com o mundo hitita, igualmente indo-europeu, cf. A. Bernabé, «Los mitos hititas sobre Kumarbi y la Teogonía de Hesíodo: forma y diversidad de concepción religiosa», Cadmo 10 (2000), 147-166. Sobre as teogonias da Ilíada, ver Il. I, 396-406; XIV, 201-207, 246; XV, 187-193. 
Para terminar esta série de exemplos de imagens aparentemente inconscientes do mundo semítico na literatura grega, gostariamos ainda de citar alguns casos em que surgem afinidades ao nível da composição textual, do uso de conceitos ou da manifestação de ideias literárias. Trata-se de um conjunto de formulações de natureza ética, próprias da literatura sapiencial, que poderiam constituir uma lista extensa, mas que restringimos a alguns exemplos elucidativos. Poderá ser significativo que, em Sófocles, se encontrem as seguintes palavras:

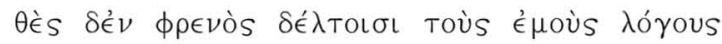

«Inscreve as minhas palavras no teu coração (phren) ${ }^{(47)}$.

Comparável a um passo bíblico do livro dos Provérbios:

כתבם על-לוח לבך

"Escreve-as na tabuinha do teu coração» ${ }^{(48)}$.

O livro dos Provérbios, composto por um conjunto de máximas sapienciais atribuídas a personagens célebres da História de Israel, abrange um período que vai do século $\mathrm{X}$ ao século $\mathrm{V}$ a.C. A composição corresponde a um tipo de literatura gnómica próxima de Os trabalhos $e$ os dias de Hesíodo, escrito em meados do século VII a.C. ${ }^{(49)}$ Mas não é apenas nestes dois livros que encontramos concepções morais, sapienciais, divinas e sagradas semelhantes. Por exemplo, Javé jura pelo Céu e pela Terra, tal como Hera jura com a Terra e o Mar como testemunhas em «Homero» ${ }^{(50)}$.

(47) S., Triptólemo frg. 540 Nauck.

(48) $\operatorname{Pr} 7,3$.

(49) Por exemplo, as sentenças sobre a esposa que se podem encontrar em $\operatorname{Pr} 31,10$ e $O p$. 702: «Uma mulher de valor, quem a poderá encontrar? O seu preço é muito superior ao das pérolas"; "Pois nada de melhor pode um homem conseguir que uma boa esposa, e nada pior que uma má.» Uma crítica a esta relação pode ser considerada em M.H. Rocha Pereira, Estudos de História da Cultura Clássica, 161.

${ }^{(50)}$ Cf. W. Burkert, «Homerstudien und Orient» in Zweihundert Jahre Homer-Forschung: Rückblick und Ausblick, ed. J. Latacz (Stuttgart/Leipzig, 1991), pp. 155-181. Dt 4,26 e Il. XIV, 272-273. Outros exemplos: S., Ant. 354 e Sl 8,7 e Gn 1,28 (homem com ideia de poder sobre a natureza); $I l$. XXIV, 527-528 e Is 45,7 e $D t 30,15$ (o bem e o mal à disponibilidade do homem); Il. VI, 146 e Pi., P. VIII, 95-96 e A., Pr. 83, 547 e Sl 90,5-6 (brevidade da vida e incapacidade do homem); Od. 9,9 e Hdt. VIII, 55 e S., OC 700-703 e Sl 128,3 (metáfora da oliveira) - a maioria parece ser matéria sapiencial derivada de um ambiente mediterrâneo comum; Hes., Op. 5-8 e $1 S m$ 2,1-10; Sl 75,4; Jb 9,6 (concepções de divindade); A., Pr. 803-806 e Gn 3,24 (os guardiães de Deus); Il. IX, 219-220; Hes., Th. 540-555 e Lv. 1,9 e Gilgamesh XI, 159-160 (aspectos do sacrifício divino). 
Ao nível da forma, Isaías escreve o que parece ser um símile homérico:

«Assim como o leão e as suas crias rugem sobre a presa, e, ainda que venha contra eles um tropel de pastores, não se deixam alarmar diante do tumulto, assim o Senhor do universo descerá para pelejar sobre o monte Sião, sobre a sua colina.» ${ }^{(51)}$.

\section{Comparemo-lo com dois exemplos da Ilíada:}

"Assim como os pastores que dormem nos campos não conseguem afastar o leão esfomeado de um corpo quente, também os dois Ájax de capacete não conseguiam afastar Heitor, o Priâmida, do cadáver» ${ }^{(52)}$,

ou,

"O Pélida entoou um longo lamento, colocando as suas mãos assassinas no peito de seu amigo, com muitos gemidos, tal como um leão de juba a quem um caçador de veados roubou as suas crias numa densa floresta e que, afligindo-se por ter chegado demasiado tarde, percorre muitos vales, buscando o caminho do homem» ${ }^{(53)}$.

Este símile aparece igualmente na Epopeia de Gilgamesh ${ }^{(54)}$.

\section{AS IMAGENS SEMI-CONSCIENTES}

Vejamos agora alguns exemplos em que a imagem das culturas semíticas surge de uma forma semi-inconsciente, isto é, em que há consciência de uma origem ou cenário oriental, mas em que se processa uma apropriação que nega aos factores intervenientes uma outra língua, condição sine qua non para se definir como estranha ou bárbara, inserindo-os na cultura grega.

O caso de Cíniras, lendário monarca de Chipre que, na Ilíada, se conta entre os reis que apoiam os Aqueus, é nesta perspectiva relevante ${ }^{(55)}$. $\mathrm{O}$

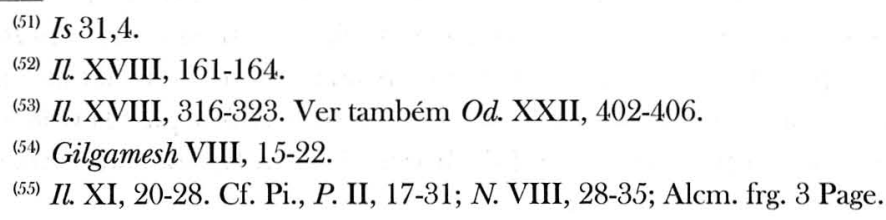


seu nome, Kıvv́pas, tem sido visto como uma forma grega de uma palavra semítica, expressa em hebraico por כנור, kinnor, em acádico por kinnaru e em fenício por kinnur, que significa «harpa» ${ }^{(56)}$. Este foi um dado suficiente para que surgissem as teses em torno da possibilidade de esta personagem homérica ser representante dos contactos entre Gregos e Semitas no II. milénio a.C. Acresce o domínio do rei, a ilha de Chipre, que manteve relações com a costa siro-cananaica desde muito cedo e está razoavelmente atestada na documentação oriental ${ }^{(57)}$. Segundo a Ilíada, Cíniras oferecera uma couraça a Agamémnon como presente de hospitalidade e de apoio à missão contra Tróia. $\mathrm{O}$ que sugere também a deslocação do rei micénico à ilha mediterrânea. É interessante notar que o poema descreve a couraça do rei micénico como adornada com $\delta \rho a ́ k o \nu T \epsilon S$, o que sugere uma iconografia igualmente oriental ${ }^{(58)}$. Junte-se a estes dados o facto de, mitologicamente, a personagem ser originária de Biblos, na Síria, ter fundado a cidade de Pafo e trazido para Chipre o culto de Afrodite, deusa com afinidades com a Ishtar/ Astarte semítica. Na Bíblia, todavia, Chipre aparece sob o nome de Kitim e, na tábua das nações do Génesis, Kitim é um dos filhos de Javan, neto de Noé, por Jafet. Isto é, para o autor bíblico, foram povos que de algum modo se identificam com os Gregos que povoaram Chipre, o que nos deixa num jogo de atribuições dos dados transmitidos pelos textos gregos e hebraicos.

Outro caso na linha do de Cíniras é o de Cadmo. Herói do ciclo tebano, o irmão de Europa tem as suas origens lendárias no Oriente. Príncipe da fenícia Tiro, uma cidade de origem semítica, depois do rapto de sua irmã Europa por Zeus metamorfoseado em touro, Cadmo obedeceu à vontade do seu pai, para que procurasse a irmã, indo para a Trácia, na companhia da mãe. Depois, ao consultar o oráculo de Delfos, soube que devia deixar

${ }^{(56)}$ No poema do ciclo dos Amores de Anat e Baal, a deusa canta, fazendo-se acompanhar de um knr.

${ }^{(57)}$ Cf. A queda de Samaria sob Sargão II; O cerco de Jerusalém por Senaqueribe; A luta pelo trono de Assardão (textos assírios); A viagem de Wen-Amon; Os relatos contra os Povos do Mar provenientes do templo de Medinet Habu em Tebas, do tempo de Ramsés III; O hino da vitória de Tutmés III (textos egípcios); O ritual para a construção de uma casa (texto hitita); que se datam entre o século XV e o VII a.C. Publicados por J.B. Pritchard, ed., Ancient Near Eastern Texts (Princeton, 1969), pp. 262-263, 282, 284-290, 356-357, 373-373. Ver ainda Gn 10,4.

${ }^{(58)}$ Protecção típica do Próximo Oriente, segundo Y. Yadin, The Art of Warefare in Biblical Land (London, 1963), pp. 84-85, 196-197, citado por C. Baurain, «Kinyras. La fin de l'âge du Bronze à Chypre et la tradition antique», Bulletin de Correspondance Hellénique 104 (1980), 277 308, que estudou o caso com profundidade, e J.P. Brown, «Kothar, Kyniras, and Kythereia», Journal of Semitic Studies 10 (1965), 197-219. 
de procurar Europa e fundar uma cidade no sítio em que uma vaca, que deveria seguir, caísse de cansaço. Encontrou então uma vaca com uma Lua como sinal em cada flanco (o que sugere temas orientais, como o da Hathor egípcia). Cadmo seguiu o animal, que parou na Beócia e aí fundou a cidade de Tebas. Posteriormente, defrentou ainda um dragão. Os textos mais antigos que possuímos que permitem conhecer a lenda datam do século $\mathrm{V}$ a.C., sendo que os fragmentos de Ferécides e Helânico ${ }^{(59)}$, assim como outros disseminados pela epopeia, pela lírica e pela tragédia, permitem que se tenha uma ideia do que se sabia acerca do herói antes dessa data. Sabemos que se acreditava na origem fenícia de Cadmo e que era descendente de Agenor ${ }^{(60)}$. Aparentemente, havia já por essa altura uma relação com a princesa Europa, cuja história aparece em Homero e Hesíodo ${ }^{(61)}$. Nessa época, todavia, Europa não era necessariamente sua irmã ${ }^{(62)}$. Outra figura

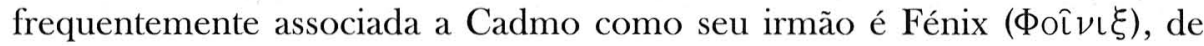
onde se origina o termo "fenícios» (申oí $\nu\llcorner\kappa \in S$ ) e cuja alusão na Ilíada tem um paralelo com a figura de Rúben no livro de Génesis ${ }^{(63)}$. Mas Heródoto é particularmente importante na afirmação da origem fenícia de Cadmo, mais em particular da sua procedência tíria; é, inclusive, e juntamente com os logógrafos, a mais antiga menção conhecida a esse facto. De igual modo, Eurípides frisa-a em três das suas peças ${ }^{(64)}$. Posteriormente, diversos autores virão a recuperar essa tradição, tendo como referência para «Fenícia» as cidades de Tiro e Sídon em particular ${ }^{(65)}$.

${ }^{(59)}$ Pherecyd., frgs. 21-22 Jacoby, Fragmente der Griechischen Historiker I A 3 e Hellanic., frg. 1 Jacoby I A 4.

${ }^{(60)}$ S., OT 268 e B. XIX 41-48; houve quase de certeza uma tragédia de Eurípides chamada Cadmo, mas não lhe conhecemos qualquer fragmento; cf. T.B.L. Webster, The Tragedies of Euripides, 161.

(61) Il. XIV, 321-322 e Hes. frg. 14.1 Merkelbach-West, Theogonia Opera et Dies Scutum.

${ }^{(62)}$ Em Hdt. I, 2, por exemplo, o rapto de Europa é feito por Cretenses. Eumelo, Estesícoro e Simónides, como outro exemplo, não aludem a qualquer relação desta heroína com o Oriente.

${ }^{(63)}$ Cf. E., Frixo, frg. 819 Nauck; escol. E., Ph. 5; Apollod., Bibliotheca II, i, 3-4. Sobre o paralelo com Rúben, cf. Il. IX, 445-456 e Gn. 35,22 e 49,4. O tema comum é o do aviltamento do leito paterno.

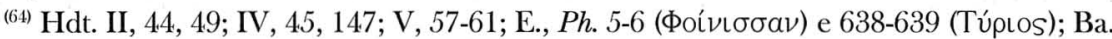

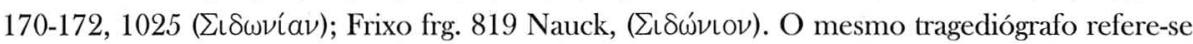
igualmente à origem fenícia de Europa em Cretenses frg. 472 Nauck; Frixo frg. 820 Nauck; Hipsípile frg. 752 Nauck, assim como Hdt. IV, 45.

${ }^{(65)}$ Dos quais destacamos E., Ph. 5-6; Ba. 170-172, 1025; Frixo, frg. 819 Nauck, variando a origem no mesmo autor, e J., $A p$. I, 10. Mas a Fenícia não foi o único espaço oriental atribuído a

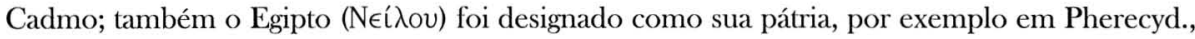
frgs. 21, 86, 87 Jacoby I A 3. 
O facto de Tebas ser a cidade fundada por Cadmo é pertinente, devido às referências arqueológicas que a região da Beócia, aliás próxima da ilha de Eubeia, tem revelado, a que se juntam os elementos literários que formulam o mito. Recordemos o contexto criado por Eurípides em Fenícias, onde o coro da tragédia é composto por mulheres originárias de Tiro, enviadas a Delfos. É também Eurípides quem conta a história dos dentes de dragão, tema oriental, pela voz do coro da mesma tragédia ${ }^{(66)}$.

No século XIX, o dado mitológico da origem de Cadmo foi aceite literalmente. Depois surgiram as opiniões mais cépticas, que criticaram o conceito de «Fenícia», passando a existir um sentido estrito para a designação, que se referia mormente às cidades da costa síria, e um sentido mais lato, que abrangia não apenas Canaã e o espaço semítico ocidental, como inclusivamente a ilha de Creta ${ }^{(67)}$. Interessa-nos, contudo, o que os Gregos entenderam como «Fenícia», e o sentido mais natural que lhe davam relacionava-se com os espaços da costa levantina, correspondente às cidades da Síria e Canaã, e que vissem Cadmo como alguém de origem que hoje designamos semítica. Cadmo foi, aliás, juntamente com Dánao e Pélops,

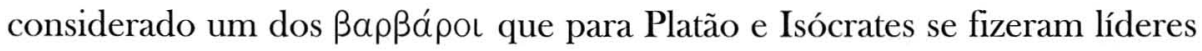
de cidades na Grécia ${ }^{(68)}$. Este é um conceito que implica que, para Platão e Isócrates, Cadmo falava outra língua que não o grego, o que não está pressuposto noutros textos.

Não é de desconsiderar que, segundo Heródoto, o alfabeto foi introduzido na Grécia pelos companheiros de Cadmo, chamando também por

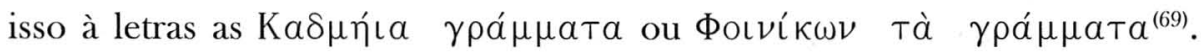
Este é um dado particularmente interessante, se tivermos em conta a proveniência fenícia do alfabeto. Os Gregos do século V a.C. interessaramse pelas origens dos povos e das relações entre uns e outros, como prova a obra de Heródoto. Trata-se de uma forma de especulação etnográfica que levou à criação de genealogias e de passados para heróis epónimos, conduzindo a leituras evemeristas dos mitos. Mas, ainda assim, o significado do seu nome em línguas semíticas é pertinente. Cadmo parece relacionar-se com o semítico qdm, em hebraico קדם ,Oriente». A Ilíada chama aos

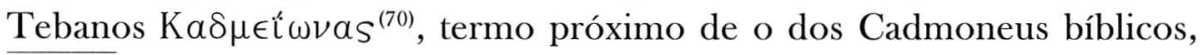
(66) E., $P h .638-689$.

(67) Várias leituras podem ser encontradas em R.B. Edwards, Kadmos the Phoenician, 51-64. ${ }^{(68)} \mathrm{Pl} .$, Mx. 245C-D e Isoc. X - Helena 68 e XII - Panatenaico 80.

${ }^{(69)}$ Hdt. V, 58-59.

(70) Il. IV, 385; V, 804 e XXIII, 680. 
בני קדם "os filhos do Oriente» ${ }^{(72)}$. Estes são elementos que se juntam à geografia oriental do mito. É ainda significativo que se torne irmão de Europa, visto que também o nome «Europa» encontra defensores para uma possível origem semítica, entre os que consideram que o antrotopónimo teve origem em ערב ('ereb), que tanto pode significar «ocidente» ou "anoitecer» como "mistura de povos» ${ }^{(73)}$. Restaria averiguar se estas deduções não foram feitas a posteriori.

Uma leitura próxima das que apresentámos para os casos de Cíniras e Cadmo é a que Tácito expõe nas Histórias, a propósito das hipóteses acerca das origens dos Judeus. O historiador escreve que uma delas afirmava que tinham tido um começo ilustre, pois descendiam dos Sólimos, povo citado nos versos de Homero $^{(74)}$. Na Ilíada, aparecem no contexto da história de

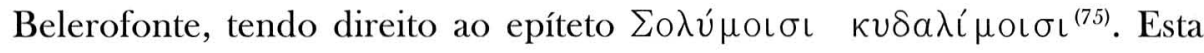
tese pretende o enobrecimento do povo, entroncando-o num outro, citado por Homero. Do etnónimo em causa, Solymni, faziam derivar o da sua capital, Hierosolyma, nome clássico de Jerusalém. Desconhecemos, todavia, a antiguidade da tese, tendo notícia dela através de Tácito ${ }^{(76)}$. De qualquer modo, sugere-se uma leitura metodologicamente semelhante às feitas para os dois heróis antes referidos que, não obstante, é feita posteriormente a Homero.

Várias outras histórias da mitologia grega incluem elementos ou cenários semíticos. Algumas surgem como gregas, mas para quem a hipótese de terem subjacente uma origem ou influência oriental é atraente. Outras são claramente adaptações de temas da literatura e mitologia semíticas, helenizados e recontados para um público grego. Exemplo disso é a história de Gilgamo, inserida na lenda de Sevécoro, contada por Eliano, autor do século II d.C. ${ }^{(77)}$ Sevécoro era um rei lendário da cidade de Babilónia a quem

(71) Gn 15,19. A antiguidade de Cadmo é sugerida em S., OT 1, sentido também atribuído a קדם.

(72) Gn 29,1.

(73) Para uma discussão do assunto, ver R.B. Edwards, Kadmos the Phoenician, 79, n. 73.

(74) Tac., Hist. V, 2.

(75) $1 l$ VI, 184. Em Od. V, 283, relaciona-se o monte Sólimo com o país dos Etíopes, também conectados com os Judeus por alguns, no tempo de Tácito. No século III a.C., Mâneton não tinha a mesma opinião, relacionando os Solimnos com os Hicsos, como se pode ler em J., Ap. I, 248.

${ }^{(76)}$ Antes de Tácito, Lisímaco (apudJ., Ap. I, 180), Eupólemo (apud Eus., HE IX, 34, 12) e Hecateu de Abdera (apud D.S. XL, 3, 3) já o referiam.

${ }^{(77)}$ Ael., NA XII, 21. 
um oráculo predisse a destronização por um neto. Sevécoro tomou medidas para que a sua filha não lhe desse netos, todavia o inevitável aconteceu e a jovem, embora prisioneira, deu à luz Gilgamo. Os guardas tentaram eliminar a criança lançando-a de uma janela, mas o jovem príncipe foi salvo por uma águia e mais tarde tornou-se rei de Babilónia. A lenda contada por Eliano tem muitas semelhanças com a de Acrísio e Perseu e com a de Rómulo e Remo, e muito poucas com as aventuras de Gilgamesh, tal como as conhecemos através das tabuinhas sumero-acádicas. A isso não deve ser estranho o facto de Eliano ser já um autor do século II a.C., pelo que a tradição que conta deve ter já sofrido diversas alterações e contaminações, sendo possível uma assimilação tardia, posterior ao período a que nos propomos estudar aqui. Mas o nome «Gilgamo» associado à realeza de Babilónia parece referir-se evidentemente à mítica personagem da epopeia sumero-semítica, Gilgamesh. Acresce como prova o facto de Eliano contar também a história da planta da imortalidade, sendo sintomático que a ela esteja associada a figura da serpente ${ }^{(78)}$. Ao que parece, este tema, presente na epopeia sumero-babilónica, como no mito do jardim do Éden, em ambos os casos protagonizada pela serpente ${ }^{(79)}$, surgia também na literatura grega arcaica e clássica. O próprio Eliano evoca os autores que lhe passaram o testemunho: Íbico, que a apresentava como a droga da imortalidade ${ }^{(80)}$ e Nicandro, poeta do período helenístico, que a inseria na composição que dedicou aos animais selvagens, contando em tom jocoso uma história em torno de uma planta da eterna juventude, cuja origem se atribuia a Sófocles ${ }^{(81)}$. Eliano cita ainda Dinóloco, Arístias e Apolófanes como fontes; contudo, não restam quaisquer textos destes poetas que o provem. Ainda que não nos pareça que haja um relação directa, o tema parece de algum modo estar presente na Odisseia e na planta $\mu \omega ́ \lambda v$, com que Hermes arma Ulisses, para que este se defenda de Circe $^{(82)}$.

\footnotetext{
(78) Ael., NA VI, 51.

(79) Gn 3,1-24. Esta forma narrativa é, por sua vez, bastante próxima da lenda das maçãs de ouro das Hespérides, já presente em Hes., Th. 215-216. A associação da serpente à longevidade advém da mudança da pele com que parece ressuscitar.

${ }^{(80)}$ Ibyc., frg. 32 Page.

(81) Trata-se de um escólio que cita a tragédia perdida de S., Kophoi Satyroi frg. 335 Nauck; cf. Nic., Ther. 343-354.

(82) Od. X, 305.
} 
Outros ciclos mitológicos trazem à cultura grega imagens do mundo semítico através dos nomes dos seus heróis e da geografia que serve de suporte cenográfico à acção das histórias. A Assíria surge nos mitos e lendas de Têutamo e Reco; a Fenícia nos de Andrómeda, Helena e Menelau, Íope, Íficlo, Sinope, Tiro (Tú pos, a não confundir com Tupẃ), Poto, Bíblis e Malcandro; a Babilónia nos de Nino e Semíramis, Parsondes, Tias, Clínis, Píramo e Tisbe; a Síria nos de Mémnon, Mirina, Siro e Adónis. Noutros casos, são simples referências: Melanípides, por exemplo, descreve as Danaides caçando na Fenícia ${ }^{(83)}$. A problemática que se colocava para Cíniras e Cadmo, contudo, coloca-se para todos estes exemplos. Apenas uma análise demorada, exaustiva e individual permitirá, eventualmente, identificar os extractos mais antigos dos mitos, permitindo-nos saber o que era já conhecido e aceite como proveniente do que hoje conhecemos como mundo semítico, pelos Gregos dos períodos arcaico e clássico. Alguns nomes são mencionados em autores antigos, mas por vezes a sua relação com o mundo semítico é tardia. Assim acontece com a amazona Mirina ou com Mémnon, inicialmente relacionado com o Egipto e a Etiópia e só posteriormente com a Síria. Na verdade, a maioria destas lendas chegou até nós através de escritores helenísticos ou mesmo mais tardios. Apolodoro e Diodoro da Sićlia são os mais comuns. Um caso paradigmático é o de Adónis. A sua história é narrada e mencionada essencialmente por Teócrito, Apolodoro, Higino, Ovídio ${ }^{(84)}$. Mas já Hesíodo, Safo e Aristófanes o referem ${ }^{(85)}$. Aliás, iconograficamente, Adónis surge mesmo representado em materiais etruscos. É porém difícil saber se o que os autores helenísticos e romanos sabiam de Adónis era o mesmo que os arcaicos e clássicos. Certa é a semelhança do nome da personagem com o hebraico אדון ('dn (86). A história narrada em seu torno, de Mirra e de Afrodite Salambo (epíteto semítico), a atribuição

${ }^{(83)}$ Melanipp., frg. 757 Page.

(84) Bion I, 72; Theoc., Id. XV; Apollod., Bibliotheca III, xiv, 4; Hyg., Fab. 58 e 161; Ov., Met. X, 298-559; e ainda Plu., Alc. 18, 5; Nic. 13, 11. As Siracusanas de Teócrito testemunham o sucesso que este culto tinha no Mediterrâneo, no período helenístico.

${ }^{(85)}$ Hes., Cat. Mul. frg. 21, citado por Apollod. III, xiv, 4; Sapph. frgs. 140(a), a mais antiga menção ao culto de Adónis, e 168 Lobel-Page e Ar., Lys. 387-389 (onde surge uma menção a

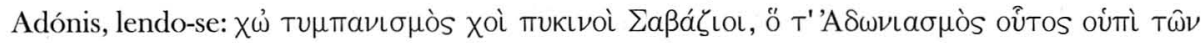

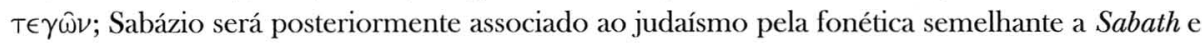
a Javé Sabaot).

${ }^{(86)}$ Significa «senhor» e é equivalente a בעל, ba'al, que exprime também o nome de algumas divindades dos panteões semíticos, nomeadamente do de Ugarit. 
da paternidade a Cíniras, as lamentações em torno da sua morte, próximas das de Ishtar e Baal na Fenícia e Canaã, jogam a favor da tese da sua origem semítica. Remontará ela ao período arcaico ou até mesmo antes? A julgar pelos testemunhos hesiódico e sáfico, provavelmente. Baal, o deus fenício, surge igualmente nas tradições gregas como Belo (Ḅ̂入os), na forma de herói assírio ou babilónico, chegando a figurar na genealogia de Dido de Cartago. Mas o seu nome aparece já em Ésquilo, significativamente ligado à genealogia de Cadmo ${ }^{(87)}$. Outra questão interessante a colocar neste âmbito relaciona-se com o período em que os Gregos travaram conhecimento com Baal. Isso poderá ter acontecido em qualquer momento dos contactos com os Fenícios e a partir de então o nome ter-se-á difundido entre os Helenos.

\section{As IMAgENS CONSCIENTES}

Até aqui considerámos essencialmente aquilo que poderíamos definir como imagens instantâneas do mundo semítico na literatura grega arcaica e clássica, pois apesar de muitas vezes existir consciência da proveniência oriental do tema, nem sempre ele é tratado como um episódio estranho à cultura grega que o aborda. É difícil saber o que deu origem ao quê, como e onde ou sequer se houve derivação ou criação simultânea de temas comuns entre povos com problemáticas comuns. Mas parece-nos inegável que a literatura grega, enquanto produto mais recente, na grande maioria dos casos, transmite imagens do mundo semítico. Interessa-nos agora propor para análise alguns passos onde as referências e alusões a esse mundo são conscientes e intencionais e, por consequência, tentam exprimir uma ideia do «outro». Elas surgem essencialmente na epopeia, na historiografia, designadamente nas Histórias de Heródoto, e em Xenofonte.

Em relação ao primeiro caso, as alusões resumem-se à presença dos Fenícios nos poemas homéricos. Não são muitos os passos onde esse povo vem referido, mas os suficientes para terem originado uma tese acerca da composição e enquadramento da Odisseia ${ }^{(88)}$ e para nos darem uma ideia do significado que esse povo tinha para os Helenos. A Fenícia aparece como

(87) A., Supp. 319.

${ }^{(88)}$ V. Bérard, Les Phéniciens et l'Odyssée (Paris, 1927); cf. F. Hartog, Mémoire d’Ulysse. Essai sur la frontière en Grèce ancienne (Paris, 1996). 
um dos países visitados tanto por Menelau ${ }^{(89)}$, durante as suas deambulações, como por Ulisses. O relato mais conhecido é provavelmente o que consta no canto XIV do poema e onde o leitor moderno pode descobrir um mapa de navegação e comércio no Mediterrâneo oriental no II. ${ }^{\circ}$ milénio a.C. ${ }^{(90)}$ Durante a conversa com o porqueiro Eumeu, Ulisses conta uma história, que por vezes lembra a de José do Egipto ${ }^{(91)}$, acerca do seu pretenso passado: disfarçado de velho cretense, o rei de Ítaca afirma ter estado na guerra de Tróia e, depois de ter regressado a Creta, embarcado para o Egipto onde acabou por se instalar durante sete anos, sob o patrocínio do

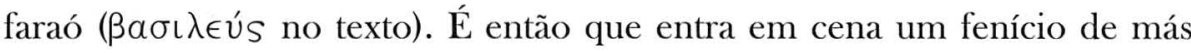
intenções que convence a personagem a segui-lo até à sua terra de origem, levando-a posteriormente em direcção à Líbia, com a intenção de a vender como escrava. Ulisses conta que teria sido providencialmente salvo por um naufrágio, provocado por Zeus. Neste relato concentra-se a essência da imagem fenícia na Odisseia. $\mathrm{O}$ «raptor» de Ulisses é possuidor de uma nau, viaja pelo Mediterrâneo oriental e, a julgar pelas palavras do protagonista, pratica o comércio, dado que pretende vender o herói como escravo, na Líbia. Devido à sua atitude pouco simpática, o fenício não recebe os melhores epítetos neste passo. O poeta diz acerca dele:

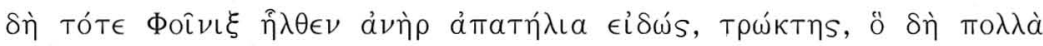

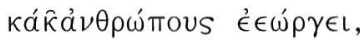

«vi um fenício manhoso, ávido, que já tinha prejudicado muitas pessoas» ${ }^{(92)}$,

e que conseguiu enganar Ulisses com a sua "astúcia». Esta ideia é, de algum modo, repetida alguns versos depois, numa outra história, desta vez contada por Eumeu ao protagonista ${ }^{(93)}$. Trata-se do episódio da sidónia, que o porqueiro relata ao rei ainda disfarçado de mendigo. Eumeu confessa-se originário de uma «ilha chamada Siro», nome que evoca a Síria, ainda que

${ }^{(89)}$ Od. IV , 83. Curiosamente, o poeta separa Sídon do resto da Fenícia, razão pela qual o verso 83 tem sido considerado uma interpolação. Mas Sídon é por vezes distinguida da restante Fenícia noutros passos, como demonstra Il. XXIII, 743-744. Ainda no verso 84 do Canto IV da Odisseia, aparecem os 'E $\rho \in \mu \beta o$, que, a julgar por Aristarco, seriam os Árabes, outro povo semítico.

(90) Od. XIV, 250-320.

(91) $\mathrm{O}$ ódio dos irmãos, o casamento com a mulher rica, a alusão à espiga, o triunfo da personagem, o acolhimento do faraó, a estada de sete anos no Egipto e o cenário egípcio de parte do relato são os elementos que recordam a história de José, em Gn 39-40.

(92) Od. XIV, 288-289.

(93) Od. XV, 403-484. 
muito provavelmente se trate de uma das Cíclades. Tendo chegado à ilha um grupo de Fenícios, diz acerca deles,

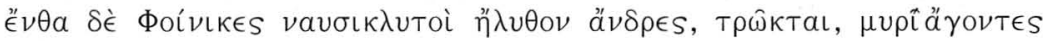

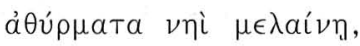

«um dia apareceram uns Fenícios, marinheiros célebres, ávidos, trazendo na sua negra nau milhares de bugigangas» ${ }^{(94)}$.

Os epítetos utilizados pelo poeta são semelhantes aos usados no passo anteriormente citado. A avidez, expressa por $\tau \rho \omega ́ \kappa \tau \eta s$, emparelha com

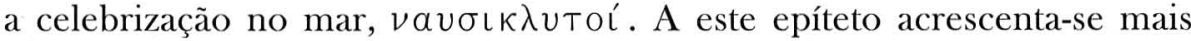

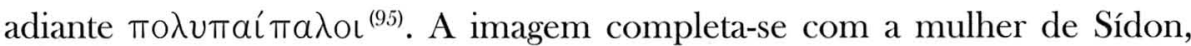

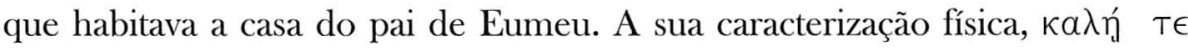

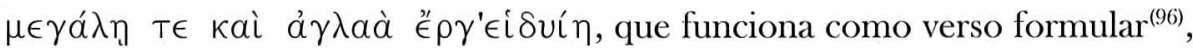
contrasta com o comportamento que demonstra ter. Tendo sido vendida como escrava por piratas táfios ao pai de Eumeu e perante a proposta de um dos Fenícios a levar de volta a casa, a sidónia decide roubar algumas riquezas e a criança de quem era serva, sugerindo a venda desta como escrava e assim, de algum modo, consumar a sua vingança. A mulher, todavia, acaba por perecer a bordo do navio fenício, «sob as flechas de Ártemis», como se de um castigo divino se tratasse e Eumeu vendido a Laertes, na ilha de Ítaca.

Raptos e vendas de pessoas, um tema posteriormente desenvolvido pelo romance helenístico, eis uma actividade que predomina na caracterização dos Fenícios odisseicos ${ }^{(97)}$. Paralelamente à imagem do marinheiro e do comerciante que contacta com diversos povos, estes Fenícios não primam pela honestidade, associando-se a ideia do «comerciante ladrão», própria daquele que está fora do círculo aristocrático das sociedades bélico-fisiocráticas, ligadas à guerra, à terra e à agricultura, como era então a dos Helenos. Ainda que, na Ilíada, o poeta afirme que Alexandre (Páris) fez exactamente o mesmo à prendadas fenícias de Sídon ${ }^{(98)}$. De igual modo, e por consequência, esses marinheiros orientais parecem não estar muito tempo

(94) Od. XV, 415-4.16.

(9.5) Od. XIV, 419.

(96) E.g., Od. XIII, 289.

${ }^{(97)}$ A imagem é recorrente também em Hdt. II, 54. Sobre esta questão, ver ainda A. Bernabé, «La mirada del Otro: imágenes de los Fenicios en los poetas griegos antiguos» in J.A. Ramos, L. M. de Araújo, A. Ramos dos Santos, org., Percursos do Oriente Antigo. Homenagem a José Nunes Carreira (Lisboa, 2004), 67-81.

(98) Il. VI, 288-295. 
presos no seu território original, permanecendo longas temporadas longe da terra que lhes pertence, tratando dos seus negócios. Aqueles contrastam assim com Ulisses, cujo anseio e preocupação principal é precisamente o regresso à casa que o viu nascer e a que se viu obrigado a abandonar.

Ainda assim, esta concepção não parece ser generalizada. Como que inserindo intencionalmente outra participação fenícia, o poeta consegue dar uma perspectiva diferente dos passos acima analisados. Ao chegar a Ítaca e encontrar-se com Atena, o herói da Odisseia conta que foram precisamente os Fenícios que o trouxeram até à sua ilha ${ }^{(99)}$. Mantém-se a imagem dos marinheiros conhecedores do Mediterrâneo, comerciantes que aceitam qualquer trabalho em troca de um pagamento. Mas os epítetos que lhes são aqui dispensados estão longe dos juízos de valor posteriormente feitos:

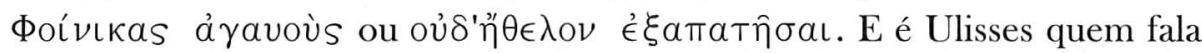
em sua defesa. Na mesma linha desta ideia, na Ilíada, as mulheres de Sídon são apresentadas como especialmente dotadas, com o verso

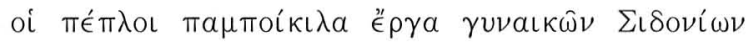

"Os véus totalmente bordados pelas mulheres de Sídon» ${ }^{(100)}$.

A habilidade artística é apanágio que continua a servir de mote para a caracterização destes Semitas, alguns cantos adiante. O poeta fala da cratera

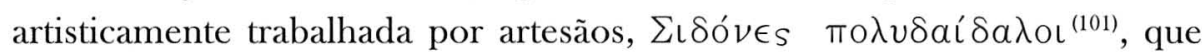
Aquiles propõe como prémio para a prova de velocidade dos jogos em honra de Pátroclo e que marinheiros igualmente fenícios tinham trazido para a Hélade como presente ${ }^{(102)}$. Como complemento destas ideias, podemos ainda acrescentar que, em Homero, está já presente a imagem do Oriente rico e luxuoso, a grandiosidade oriental mais tarde desenvolvida por outros autores e aqui particularmente apreciada no mundo semítico da Fenícia. É o que transparece de expressões como $\Sigma\left\llcorner\delta o v i ́ \eta \nu ~ \epsilon u ̉ ~ v a\left\llcorner o \mu \epsilon ́ v \eta \nu^{(103)}\right.\right.$,

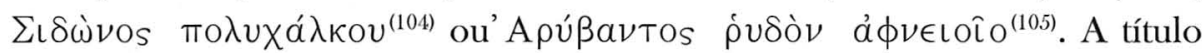
de curiosidade, refira-se que o poeta não revela em que língua comunicavam Gregos e Fenícios.

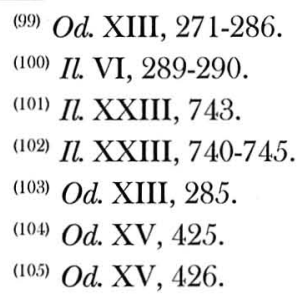


A natureza da informação acerca do mundo semítico que podemos encontrar em Heródoto é todavia diferente. Há que ter em conta que um dos objectivos fundamentais da obra do historiador é a demonstração de formas opostas de definir culturas que, até certo ponto, levaram ao conflito entre Helenos e Bárbaros ${ }^{(106)}$. Estes são diferentes daqueles e isso é ponto assente. Assim, é nesse contexto que se apresentam os logoi que descrevem os países estrangeiros aos Gregos, por onde os Persas, agora seus inimigos, passaram e dominaram antes. As descrições passam imagens geográficas e etnográficas importantes.

Apesar de existirem algumas alusões aos Fenícios $^{(107)}$, nomeadamente no proémio em que se expressam opiniões sobre os conflitos em análise, o historiador de Halicarnasso disserta relativamente pouco sobre este povo nas Histórias. Mas, ainda assim, Heródoto mantém nas suas palavras parte da imagem que os Poemas Homéricos tinham cristalizado. São os homens que «empreenderam longas navegações: com mercadorias egípcias e assírias, aportaram a diversas regiões, entre as quais estava Argos» ${ }^{(108)}$, que praticam o comércio pelo Mediterrâneo, como são os autores de $\operatorname{raptos}^{(109)}$. Aliás, com o recurso à participação dos Fenícios, Heródoto enceta uma forma de racionalização dos mitos que eram contados no seu tempo. A determinada altura, promete também dedicar um dos seus logoi aos Assírios ${ }^{(110)}$, mas esse povo ficou reduzido a uma digressão pela cidade de Babilónia, semítica, mas não necessariamente assíria. A capital de Nabucodonosor assumiu assim o papel de grande logos semítico na obra de Heródoto. Efectivamente, o grande espaço urbano descrito nas Histórias corresponde à capital caldaica e aqueménida (secs. VII-VI a.C.), não à que designamos por assíria, que lhe é anterior (secs. IX-VIII a.C.). O historiador foi certamente influenciado pela memória do poder que a propaganda de terror dos reis assírios difundiu e

(106) Sobre esta questão, diz H.R. Immerwahr, Form and Thought in Herodotus (Atlanta, 1966), p. 25: «the main sequence of logoi is not primarily an account of East-West conflicts, but a description of the activities of Eastern powers".

${ }^{(107)}$ Hdt. I, 1-2; podem encontrar-se outras menções em II, 44 e V, 57. Ver A. Bernabé, «La mirada del otro, 2: Referencias a los Fenicios en Heródoto» in A. González Blanco, J.P. Vita, J.A. Zamora, eds., De la tablilla a la inteligencia artificial. Homenaje al prof. Jesús-Luis Cunchillos en su 65 aniversario (Zaragoza, 2004), 67-81.

${ }^{(108)}$ Hdt. I, 1.

${ }^{(109)}$ Hdt. I, 1; foi já notado que a narração do rapto de Io em I, 5 se assemelha ao da sidónia, ama de Eumeu, em Od. XV, 415-416. Cf. M.H. Rocha Pereira, J. Ribeiro Ferreira e M.F. Sousa e Silva, eds., Heródoto- Histórias, livro $1 .^{\circ}$ (Lisboa, 1994), p. 54, n. 3.

${ }^{(110)}$ Hdt. I, 106, 184. 
pela cultura persa, que designou a região por províncias da Assíria e Babilónia, não existindo uma correspondência perfeita entre o que foi o território, a potência histórica dos Assírios e a satrapia aqueménida. De qualquer modo, a sua fundação, povoamento e cultura são de origem semítica.

Heródoto chega à descrição da Babilónia através da exposição da origem e desenvolvimento do poder dos Persas, traçando uma linha de continuidade que se inicia em Ciro e nos costumes dos medo-persas, passando pela acção de Cambises no Egipto, expedições de Dario, batalha de Maratona e avanço e retirada de Xerxes. O autor não deixa de questionar o poder oriental, mantendo uma visão esquemática da política «imperialista» da Pérsia. No seio do grande mundo urbano da Ásia semítica, de que diz,

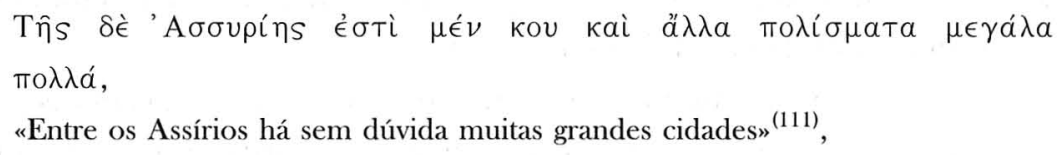

Babilónia aparece como uma das praças conquistadas por Ciro, advindo daí $o$ interesse pela fortaleza que caiu traiçoeiramente nas mãos dos inimigos dos Gregos. O historiador recolhe informações acerca dos Babilónios e seu território, fazendo o levantamento de material etnográfico, que aproveita para o seu objectivo, procurando talvez razões para explicar as dificuldades com que o despotismo oriental se defrontou.

Babilónia é vista como a cidade mais importante (depois da destruição de Nínive) da região, pois era sede de poder. A descrição etno-geográfica inicia-se com a avaliação do perímetro da cidade, assunto que tem sido considerado exagerado nas palavras do historiador, mas que corresponde ao objectivo de mostrar a grandeza dos Estados orientais. Assim se percebe a importância e dimensão que a cidade tinha no imaginário ocidental, já no século $\mathrm{V}$ a.C.: diz Heródoto que Babilónia era um aglomerado urbano que não tinha igual na Antiguidade. $\mathrm{O}$ historiador disserta, descrevendo o espaço, não ocultando a sua admiração pela magnificência da outrora capital do mundo. No livro III das suas Histórias, refere que, logo após a expedição naval de Samos, estalou uma revolta contra a hegemonia persa em Babilónia, em consequência da qual Dario fez empalar três mil homens como castigo e aviso aos Babilónios ${ }^{(112)}$. Provavelmente tratou-se apenas de uma parte da

(111) Hdt., I, 178.

${ }^{(112)}$ Hdt., III, 159. 
população masculina revoltosa, dado que os prisioneiros eram necessários como mão de obra escrava e para a manutenção do território conquistado. O Autor grego alude depois à atenção política que Dario deu às 50000 mulheres feitas prisioneiras, o que dá uma ideia da densidade demográfica do aglomerado, pelo menos para os séculos VI-V a.C. A comprovarem-se estes números, Babilónia era, para o seu tempo, uma cidade grande. Mas os exageros dos números pretendem acentuar essa imagem de grandeza, magnificência e poder. $\mathrm{O}$ exagero e os pormenores algo patéticos não passaram despercebidos no tempo de Heródoto e Aristófanes, que também satiriza os Fenícios circuncidados, demonstra-o em As Aves ${ }^{(113)}$. Aliás, o tema desta cidade e do povo que a habitava aliciou este contemporâneo de Heródoto, por mais que uma vez, como demonstra a comédia, cujo texto se perdeu, intitulada Os Babilónios ${ }^{(114)}$.

A atenção aos pormenores urbanísticos, as referências à riqueza inesgotável da cidade, como a atenção aos pormenores económicos, a importância dos rios, que garantiram uma economia próspera e um desenvolvimento civilizacional considerável na região, desempenham igual função de caracterizar a magnificência do país ${ }^{(115)}$. Heródoto afirma que, quando a invadiu (539 a.C.), Ciro dividiu a Babilónia em regiões para que lhe pagassem tributo. Só a satrapia que levava esse nome alimentava o rei persa durante quatro dos doze meses do ano. O resto da Ásia supria os restantes oito meses da corte persa, o que demonstra a importância que o território tinha comparativamente ao resto da região, que incluía as satrapias de Gândara, Bactriana, Pérsida, Média, Elão e Assíria. Heródoto fornece a

${ }^{(113)}$ Ar., Av. 507, 551-552, onde se lê uma paródia à «tecnológica» Babilónia de Heródoto, a propósito da construção da muralha da Nefelocucolândia. A imagem desta Babilónia foi já analisada porJ. MacGinnis, «Herodotus' description of Babylon», Bulletin of the Institute of Classical Studies 33 (1986), 67-86. O enquadramento do logos pode ser mais bem compreendido com F. Hartog, Le miroir d'Hérodote. Essai sur la représentation de l'autre (Paris, 1980) e M.F. Silva, «O desafio das diferenças étnicas em Heródoto», Humanitas 52 (2000), 3-26. A brincadeira aristofânica à circuncisão será um tema prolífico e recorrente nas imagens semíticas de autores posteriores.

(114) Sobre este texto, ver M.F. Silva, «O Estrangeiro na Comédia Grega Antiga», Humanitas 51 (1999), 23-48.

(115) Hdt. I, 193. As relações de grandeza que o historiador dá quanto à produtividade cerealífera são de facto extraordinárias: 200/1 e até mesmo 300/1. As folhas de trigo candial e a cevada atingiam até quatro dedos de largura e o milho miúdo e o sésamo (do qual usavam o seu líquido espesso em vez de azeite) cresciam de tal modo que Heródoto se abstém de falar muito neles, receando a incredulidade de muitos de seus leitores. De qualquer forma, estes dados significam que a produtividade da região era bastante grande. 
relação dos tributos, fixos em talentos de prata, sob o reinado aqueménida de Dario, comprovando assim a riqueza da capital semítica ${ }^{(116)}$. Aí, Babilónia ultrapassa qualquer contributo, atestando a sua supremacia económica sobre o restante das satrapias. $\mathrm{O}$ recurso à comparação demonstra-o com eficácia.

Outro tipo de informação relaciona-se com a atitude religiosa destes semitas. As poucas referências às divindades locais surgem na forma de uma interpretatio graeca da religião: Baal Marduk aparece como Zeus Belo

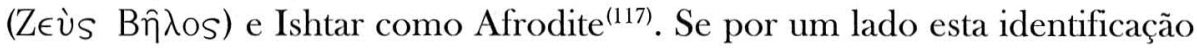
abona em favor das teorias que vêem naquela deusa semítica a raiz da deusa grega do amor, por outro confirma a possibilidade de o Belo da mitologia grega ter a sua origem num dos principais deuses do panteão babilónico. A informação religiosa complementa alguns dados sobre a condição feminina. A dedicação das mulheres babilónicas, que consistia numa forma de prostituição sagrada, parece a Heródoto algo de estranho e desprezível:

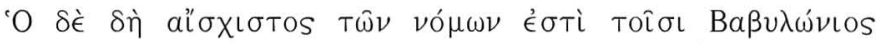
«O mais condenável dos costumes babilónicos» ${ }^{(118)}$.

O historiador parece assim demonstrar uma forma de respeito para com as mulheres, que de algum modo contradiz o tratamento de «gineceu», com que por vezes se generaliza a análise da mulher grega. Ainda assim, Heródoto

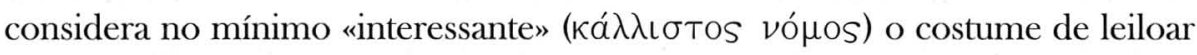
as filhas. A diferença em relação ao caso anterior situa-se, provavelmente, no problema do património, dado que uma coisa era leiloar uma filha para casamento e outra era uma mulher entregar-se como hieródula a um qualquer indivíduo, correndo o risco de gerar um filho sem ascendência definida para a herança do património. Percebe-se aqui a percepção herodotiana do universalismo em determinados costumes, independentemente da etnia ${ }^{(119)}$. $\mathrm{O}$ contraste percebe-se quando o Autor condena o desuso do costume e o aumento da prostituição na cidade do seu tempo. É também como «sábia»

(116) Hdt. III, 89-94.

${ }^{(117)}$ Hdt. I, 181, 199. Heródoto afirma que a «Afrodite dos Assírios» se chama Milita, o que poderá ser uma transcrição da forma Belit.

(118) Hdt. I, 199.

${ }^{(119)}$ Cf. M.C. Fialho, «Helenos e Bárbaros em Ésquilo. Autognose e problematização do Eu na representação do Outro» in Máscaras, Vozes e Gestos: nos caminhos do Teatro Clássico, coord. M.F. Brasete (Aveiro, 2001), pp. 51-69. 
que o historiador vê a ideia de levar os doentes para a praça pública, em busca da sugestão da cura, que não se coaduna, no entanto, com o que sabemos dos conhecimentos médicos dos Babilónios ${ }^{(120)}$. Talvez surja como etiologia para a ideia de "sábios» que os Caldeus angariaram na Antiguidade Clássica.

Mas é ainda através das mulheres que o historiador tece outro tipo de elogios. As figuras de Semíramis e Nitócris servem de pretexto para a admiração. Heródoto atribui à rainha Semíramis a construção de diques, ao longo do Eufrates, que permitiam a cheia e o alagamento de todo o território junto à cidade ${ }^{(121)}$. Semíramis é muito provavelmente a rainha Sammuramat, esposa do rei assírio Shamshi-Adad V (823-811 a.C.) e mãe de Adad-Nirari III (810-783 a.C.), que, por alguma razão, ganhou notoriedade entre os Gregos ${ }^{(122)}$. Posteriormente, o romance helenístico de Nino e Semíramis, de que nos restam apenas alguns fragmentos, confirmará essa fama ${ }^{(123)}$. O facto de o historiador citar uma personagem de raízes efectivamente assírias, aliada à menção de Nínive ${ }^{(124)}$, poderá apontar no sentido de existir a intenção de escrever sobre a Babilónia assíria e não caldaica ou aqueménida. Isso mostra a confusão historiográfica que então dominava. Parece ser também sintomático o silêncio sobre uma figura como Nabucodonosor. Aliás, é à rainha Nitócris que, curiosamente, o historiador atribui um maior e mais importante número de obras públicas na cidade, produto de um pensamento económico-estratégico, inusitado no feminino, pelo menos entre os Helenos ${ }^{(125)}$. Tratar-se-á de uma forma de desprestigiar o Outro? Ou tão somente de salientar o seu exotismo? De alguma forma, o protagonismo feminino oriental pairava já na persa Atossa de Ésquilo. A sabedoria Nitócris ganha também concretização com a epígrafe que lhe é atribuída ${ }^{(126)}$. A associação sabedoria/riqueza/feminilidade parecem fazer

${ }^{(120)}$ Hdt. I, 196.

(121) Hdt. I, 184.

(122) Talvez através de uma tradição popular, transmitida por via persa, que uniu esta rainha histórica, que foi regente da Assíria, às figuras da rainha Naqîa-Zakutu e da deusa Ishtar.

(123) C. García Gual, Los orígenes de la novela (Madrid, 1988), pp. 191-200.

(124) Hdt. I, 178.

${ }^{(12.5)}$ Hdt. I, 185. Alguns consideram que Nitócris é uma personagem imaginada, para a qual os historiadores não encontraram correspondência. Outros consideram-na uma deformação da figura e nome de Nabucodonosor (605-562 a.C.), visto que as obras que lhe foram atribuídas por Heródoto foram feitas por aquele rei. Mas H. Lewy, "Nitokris-Naqîa”, JNES 11, 1952, 264-286, considera que se trata da rainha Naqîa-Zakutu, esposa de Senaqueribe da Assíria (704-681 a.C.) e mãe de Assardão (680-669 a.C.), que estava no poder aquando da revitalização de Babilónia.

${ }^{(126)}$ Hdt. I, 187. 
parte do mesmo esquema de demonstração do estrangeirismo e diferença do Outro. De qualquer modo, a mulher semítica, mais concretamente a babilónica, sai a ganhar das palavras de Heródoto de Halicarnasso, que acabou por contribuir para propagar a ideia da mulher oriental emancipada, que terá o seu clímax na Cleópatra VII dos textos greco-latinos.

Por fim, apesar de Heródoto não fazer qualquer alusão directa aos Hebreus, ou sequer aos Judeus, a referência aos Sírios da Palestina que praticavam a circuncisão por influência egípcia parece dizer-lhes respeito ${ }^{(127)}$. Num outro passo, o historiador refere-se a Má $\gamma \delta \omega \lambda$ os, cidade que tem sido identificada com a Meguido bíblica ${ }^{(128)}$. Se assim for, o texto em questão alude à batalha de Meguido, em que o rei Josias de Judá morreu às mãos do faraó Necao. De qualquer modo, é possível que o historiador tenha visitado a costa siro-palestinense, no contexto das suas viagens orientais ${ }^{(129)}$.

A imagem que Xenofonte transmite do mundo semítico centra-se igualmente na da cidade de Babilónia. Aqui não se trata de um logos dedicado a esse espaço e cultura semítica, como acontece em Heródoto, mas de referências várias que se justificam pelo contextos dos seus interesses literários. Através de pretextos, descobrimo-la em algumas das suas obras: na Ciropedia, nas Helénicas e na Anábase. A Ciropedia centra-se na formação do chefe persa. O texto contém elementos do conto popular, da biografia e do romance, que reencontraremos difundidos na cultura helenística e que coexistem com a narrativa política e militar. Um tema que se torna profícuo e desenvolve, em grande parte, graças às conquistas de Alexandre e à experiência dos Gregos no Levante e que alguns autores chamaram de «tratamento romântico do Oriente» ${ }^{(130)}$. Nas Helénicas, Xenofonte pretende escrever uma história essencialmente político-militar, rejeitando elementos que reaparecem em outras obras. A Anábase relata a epopeia de dez mil soldados gregos que, arregimentados por Ciro em 401 a.C., tentaram derrubar Artaxerxes, seu irmão, que sucedera a Dario no trono da Pérsia.

(127) Hdt. II, 104; J., AJXVIII, 262 e Ap. I, 168-169 confirma essa sugestão.

${ }^{(128)}$ Hdt. II, 159; cf. 2Rs 23,29-30 e 2Cr 35,20-24. Há quem veja em Mágdolo a igualmente bíblica Migdol (Ex 14,2), situada na fronteira egípcia com a Palestina. Foi também já sugerido que II, 172, tenha relação com Is 44,12-20 e $J r$ 10,3-5, mas pode tratar-se de uma simples coincidência de concepções.

${ }^{(129)}$ Hdt. II, 44, testemunha a sua estada em Tiro.

(130) P.E. Easterling and B.M.W. Knox, The Cambridge History of Classical Literature, IGreek Literature (Cambridge, 1985), p. 463. 
Tendo-se reunido em Sardes (cerca de 13000 Gregos e 100000 Asiáticos), Ciro encaminhou o grosso do exército para Babilónia, onde se daria o encontro decisivo, na batalha de Cunaxa. Perecendo no confronto, Ciro deixou dez mil soldados gregos que, apesar de vencedores, ficaram entregues a si próprios, no seio de um «império» estrangeiro, pelo que empreenderam a famosa retirada de retorno à Hélade. Nos três textos, Xenofonte usa a sua vivência e experiência do conhecimento directo que adquiriu quando contactou com a Babilónia caldaico-aqueménida.

Do confronto com a cidade mítica, transmite-se uma vez mais a ideia de grandeza. Diz Xenofonte que, para a atacar, foi necessário a Pérsia organizar a sua cavalaria e carros de guerra, com o auxílio das outras satrapias, concedendo propriedades fundiárias e palácios aos respectivos sátrapas, para que estes, uma vez alimentados, colaborassem na conquista ${ }^{(131)}$. O poder e a grandeza são sustentados pelas riquezas, pelos tesouros que a cidade respira, pela prosperidade económica, pela ideia de opulência. As descrições que Xenofonte dá da fauna, da flora, da geografia física, da produtividade $^{(132)}$, dos pormenores urbanísticos (também ele é fascinado pela célebre arquitectura neo-babilónica), que não raras vezes atinge igualmente o exagero retórico, constróem essa imagem ${ }^{(133)}$. Num passo da Ciropedia, para enfatizar o carácter do chefe persa, o autor refere que Ciro, embora admirasse e reconhecesse as riquezas e tesouros da cidade, preferia a mão da filha de Góbrias, um babilónio, a todas essas riquezas ${ }^{(134)}$. Num outro passo, Babilónia é referida como a escolha dilecta de Ciro para passar o Inverno, pois era o coração do seu domínio, mas também «uma cidade maior que todas as cidades ilustres e a mais magnífica» ${ }^{(135)}$. Neste sentido, os textos de Xenofonte complementam os de Heródoto.

${ }^{(131)} \mathrm{X} .$, Cyr. VIII, vi, 8, 10-11.

${ }^{(132)}$ Leiam-se as alusões ao trigo em X., An. I, v, 5-7; Cyr. V, iv, 40; cf. Hdt. I, 193; à forragem em Cyr. V, iv, 40; cf. menções ao milho miúdo, sésamo, tâmara e linho em Hdt. I, 193, 198.

(133) X., Cyr., VII, v, 13, 22; An., I, v, 1-2, 5-7.

(134) X., Cyr., V, ii, 8. Efectivamente, ali estiveram os tesouros de Sardes, evacuados antes da entrada de Ciro; o espólio de Ezequias; a riqueza que Salomão acumulara no templo de Javé; as riquezas de Susa, Persépolis e Parsagade, avaliadas em mais de 50000 talentos $(500$ toneladas de prata); o dinheiro de Ecbátana, a quantia de 180000 talentos (1800 toneladas de prata), e de Arbela, 4000 talentos (40 toneladas de prata).

(135) Ciro passava os sete meses de Inverno em Babilónia, pois era a região mais quente, e os três meses de Verão em Susa. X., Cyr., VIII, vi, 19-20, 22 e VII, v, 58. 
Quando comparados ao pormenor, há diferenças em relação às imagens de Babilónia em ambos os autores, mas a sua essência mantém-se. As diferenças nas ênfases assentam nas razões e objectivos que movem cada um dos agentes, apesar de o denominador comum se chamar Pérsia. A percentagem de referências por autor coincide com os objectivos e intenções de escrita subjacentes a cada um deles. Heródoto e Xenofonte complementam-se, mantendo a ideia que vinha de autores anteriores e transferindo-a para a posteridade: o mito da cidade rica, pluricultual, centro de poder político e militar, a cidade-esplendor e prosperidade, a opulência oriental em geral, a grande cidade dos Semitas. Logo a seguir, Aristóteles dirá ser necessário um território tão grande como o de Babilónia para suportar 5000 habitantes no ócio, bem como o mesmo número de mulheres e de servos ou outro território de extensão ilimitad $a^{(136)}$. A história da rainha Nitócris ilustra bem essa ideia. Talvez por essa razão, o texto mais paradigmático seja o de Heródoto, ao demonstrar que, para possuir fortuna na cidade acumuladora de tesouros, não era necessário abrir um túmulo, profanar uma sepultura e saquear um morto. Tal era a abundância de riqueza. Dá-se mesmo apenas uma explicação para quem o fizesse: «Se não fosses tão ávido de riquezas e tão ganancioso, não abririas o túmulo dos mortos» ${ }^{(137)}$.

\section{Conclusões}

Das considerações que tecemos, é possível sistematizar algumas conclusões. As primeiras fontes literárias gregas permitem deduzir que as relações entre o mundo grego e o mundo semítico são antigas, porém pouco explícitas. Trata-se de vestígios indirectos, presentes em vocábulos, caracterização de personagens, antro-topónimos, provavelmente insignificantes para os Helenos coevos mas significativos para os investigadores de hoje. As dificuldades assentam nas datações, na falta de dados concretos que permitam dizer quem importou o quê, de onde e para onde se importou ou

(136) Arist., Pol., II, iii, 3-4. O mesmo autor diz adiante que uma cidade não se mede pelo espaço que as suas muralhas definem, pois seria impossível lançar muralhas em torno do Peloponeso para com elas definir Esparta, aplicando o mesmo exemplo a Babilónia, Pol., III, i, 12. No século I a.C., Babilónia volta a estar subjacente no romance de Nino e Semíramis.

(137) Hdt. I, 187. 
exportou, havendo ainda a hipótese das formulações simultâneas, resultado de contextos comuns. Apenas a antiguidade dos apogeus civilizacionais e de alguns materiais que revelaram as produções literárias, bem como a relativa deformação dos modelos, nos permitem inferir que o Oriente semítico antecedeu, muito provavelmente, o Ocidente grego. Mas ainda assim restam-nos as preocupações colocadas pela problemática das oralidades e suas transmissões e pelos condicionalismos comuns que frequentemente originam respostas comuns. Indicar soluções é ainda problemático. É, todavia, inegável que Gilgamesh, Ulisses e Aquiles têm muitas afinidades, que nomes como os de Cadmo e Cíniras soam a semitismos, que as teogonias e cosmogonias gregas lembram as do Próximo Oriente, que os poetas arcaicos e clássicos usaram palavras e conceitos e fizeram reflexões que ocorrem nas línguas hebraica, fenícia e acádica. Ao serem ditos e contados em grego e ao entrarem no vocabulário grego perderam o sentido de estrangeirismo e de identidade bárbara que define as relações do Homem Grego com o "Outro». Mas para nós significam pistas de investigação. De qualquer modo, a cultura europeia de matriz helénica tem como modelos manifestações que encontramos já no oriente e cujas imagens surgem na literatura grega desde o seu período arcaico.

Uma segunda perspectiva entrevê no mundo grego histórias cujo cenário é assumidamente oriental, mais especificamente semítico. As origens sirofenícias de algumas personagens, o contexto babilónico de outras, as viagens a esses territórios iniciam a cultura grega num olhar para o Oriente, sem que porém ainda se evidencie ou faça transparecer o estrangeirismo. Antes pelo contrário, estas histórias são na sua grande maioria apropriadas pelos autores gregos, como parte de uma herança que reclamam, fazendo-as «falar» em grego. A problemática instala-se, contudo, quando verificamos que alguns dos poetas e historiadores que nos deram a conhecer esses heróis e nos passaram essas imagens são tardios, apesar de recuperarem tradições anteriores ao seu tempo. Ainda assim, não é possível datá-las com uma certeza total. Apolodoro e Diodoro da Sicília não servem como argumentos de autoridade para afirmarmos que nos períodos arcaico e clássico os Helenos já se relacionavam com uma mitologia de raiz semítica. As nossas perplexidades só aumentam quando encontramos esses vestígios em Homero, Hesíodo, Sófocles ou Eurípides.

Por fim, as imagens conscientes. Neste ponto, estamos no campo da consciência do olhar para o Outro, da definição cultural e da alteridade. 
Estas enraízam-se nos Poemas Homéricos e na ideia que se faz do «fenício» e culminam nas descrições que historiadores como Heródoto, e em parte Xenofonte, fazem de uma cidade como Babilónia. Nestes, é essa capital que representa o mundo semítico. Outros povos semíticos que aparecem nas suas obras têm uma importância menor, o que certamente se deve à proximidade histórica da hegemonia neo-babilónica e à sua relação com os Persas. Ainda que não haja uma percepção do que teria sido efectivamente a civilização babilónica, destaca-se o que parece importante para definir o terceiro que criou obstáculo ao inimigo persa (ambos desempenham a função do Outro), e é isso que estabelece a diferença em relação ao Eu e que, por consequência, o define ${ }^{(138)}$. As comparações de Heródoto com a realidade helénica, de que é exemplo a menção à figueira, à oliveira e à vinha ${ }^{(139)}$, comprovam-no. Não há, contudo, obviamente, consciência de que se está perante um semita, ou que um fenício e um babilónio pertencem ao mesmo ramo linguístico. Ambas as categorias são inseridas naquilo que um heleno entendia por "Asiático" e, quando muito, a noção da diferença é a que se estabelece entre Helenos e Asiáticos. Assim se formula em Heródoto e também em Xenofonte. Por exemplo, a grandeza de Babilónia corresponde à ostentação oriental, própria do despotismo e da ausência de liberdade do cidadão comum. Os Persas postulam a mesma filosofia que os Babilónios. Os Helenos não. E é a ameaça à sua diferença, de que têm consciência, que pretendem combater. Para isso, serve-lhes de modelo uma das importantes cidades dos Semitas. Eis as principais funções das mais antigas imagens desses povos na literatura grega, que é como quem diz europeia.

(138) M.C. Fialho, «Helenos e Bárbaros em Ésquilo», passim. ${ }^{(139)}$ Hdt. I, 193. 


\section{Série}

\section{Documentos}

Imprensa da Universidade de Coimbra

Coimbra University Press

2005

- U

C - 